Int. J. Dev. Biol. 56: 369-375 (2012)

doi: $10.1387 / \mathrm{ijdb} .113487 \mathrm{zc}$

\title{
Stable expression of Y-box protein 1 gene in early development of the abalone Haliotis diversicolor
}

\author{
JUN CHEN ${ }^{1,2, *}$, ZHI-SEN CHEN ${ }^{2,3}$, ZI-XIA HUANG ${ }^{1,2}$, CAI-HUAN KE ${ }^{1,2}$, JIE ZHANG $^{1,2}$, \\ YI-XIANG ZHONG ${ }^{2}$, WEI-WEI YOU ${ }^{2}$ and JING ZHAO ${ }^{2}$
}

\begin{abstract}
${ }^{1}$ State Key Laboratory of Marine Environmental Science, Xiamen University, ${ }^{2}$ Department of Marine Biology, College of Ocean and Earth Sciences, Xiamen University and ${ }^{3}$ Quanzhou Fishery Technology Promotion Station, Quanzhou Oceanic and Fishery Bureau, Fujian Province, China
\end{abstract}

\begin{abstract}
Abalone animals are import models for the study of the early development of marine invertebrates. However, systematical evaluations of internal control genes (ICG) have seldomly been performed. In this study, ten candidate genes were cloned and surveyed for their stability throughout the early developmental period of $\boldsymbol{H}$. diversicolor using qPCR. In a period from fertilized egg to postlarva, three genes, Y-box protein 1 (YB1), ornithine decarboxylase antizyme 1 (OAZ1) and eukaryotic translation initiation factor $5 \mathrm{~A}$ (EIF5A), were found to be the most stable and could be used as ICGs. It is suggested that using two genes jointly, such as $Y B 1$ and $O A Z 1$, could be sufficiently reliable to normalize the temporal dynamics of other genes. Normalized by YB1/OAZ1, some rough features of early development of a small abalone were characterized. This is the first report of the temporal dynamics of metabolic activities and overall mRNA abundance of abalone animals in early stages. It is also the first time the multi-functional gene $Y B 1$ has been described as an internal control for early developmental biology studies. Phylogeny and function of YB1 are further discussed.
\end{abstract}

KEY WORDS: abalone, quantitative PCR, internal control, ICG, 1 -box protein 1, OAZ1

Abalone animals not only are high-value fishery resources worldwide (Gordon and Cook, 2001), but also are important models to studying early development of marine invertebrates, especially settlement and metamorphosis (Jackson et al., 2002, Jackson et al., 2005, Williams et al., 2009). Abalone embryogenesis includes spiral cleavage, mesentoblast formation and a trochophore larval stage. After hatching, trochophore larvae undergo torsion and become free-swimming veligers. Veligers are lecithotrophic and they become competent after a short pelagic stage of about 2-4 days and then can be induced to settle and metamorphose by environmental cues (Sawatpeera et al., 2001). After that, larval structures, such as the velum and larval retractor muscle, are destroyed and adult morphogenetic program is completed (Jackson et al., 2002). Short period (3-5 days) from fertilized egg to settlement of abalone involves quick histogenesis that distinguishes from relative slow developmental processes of model animals such as fruit fly, frog and mouse. It implies during this early developmental period, the temporal expressions of most of the genes will be dramatically fluctuating. It was reported that during a more narrow period, pe- lagic-benthic transition, transcriptional changes of abalone Haliotis asinina are widespread (Williams et al., 2009).

Widespread transcriptional changes prevent some modern molecular biological approaches, such as Real-time PCR (qPCR), being accurately applied to study gene temporal expressions. qPCR is the best and fastest method to assess the level of mRNA, however, accurate application of qPCR method requires a set of carefully selected and validated housekeeping genes for normal-

\footnotetext{
Abbreviations used in this paper: 19VEL, veliger at $19 \mathrm{hpf}$; 144PL, postlarva at $144 \mathrm{hpf}$; 2CELL, 2-cell stage; 58VEL, veliger at $58 \mathrm{hpf}$; 74VEL, late competent veliger at 74 hpf; COXI, cytochrome c oxidase subunit 1; COXII, cytochrome c oxidase subunit 2; CSD, cold-shock domain; EIF5A, eukaryotic translation initiation factor 5A; hpf, hours post-fertilization; ICG, internal control gene; MORU, morula stage; $\mathrm{mtETC}$, mitochondrial electron transport chain; ND5, NADH-ubiquinone oxidoreductase chain 5; OAZ1, ornithine decarboxylase antizyme 1; PABP1, polyadenylate-binding protein 1; qPCR, quantitative PGR; RPL3, 60S ribosomal protein L3; RPS 18, 40S ribosomal protein S18; TROC, trochophore stage; TUBB, beta-tubulin; GV, coefficients of variation; YB1, Y-box protein 1.
}

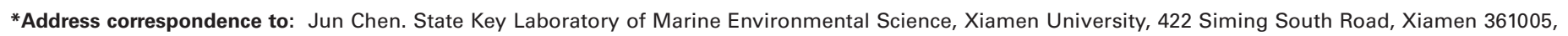
China. Tel: +86-592-218-7420. Fax: +86-592-218-7420. e-mail: chenjun@xmu.edu.cn

Supplementary Material (two photos) for this paper is available at: http://dx.doi.org/10.1387/ijdb.113487jc 
ization purposes (Wan et al., 2011). Internal control genes (ICG) should be stable across various biological conditions or treatments such as different tissues, different development stages or different environmental cues (Vandesompele et al., 2002). Some commonly used housekeeping genes, such as $\beta$-actin, tubulin and $18 \operatorname{SrRNA}$, were unstably expressed in some circumstances (Radonic et al., 2004). Though there were studies to explore temporal expressions of abalone development-related genes, such as axial patterning Hox genes (Giusti et al., 2000) and myogenesis-related Mox genes (Degnan et al., 1997), systematical ICG evaluations for developmental studies of abalone were seldom performed. Most evident ICGs, Has-NACA, Has-DAu1506 and Has-ubiquitin, were chosen from microarray expression data with the least variable expression across pelagic-benthic transition stages (Williams et al., 2009). However, the validation of these three ICGs in whole early developmental period of abalone was uncertain.

Abalone $H$. diversicolor is a major cultured shellfish in south coastal areas of China. Prior studies of our lab have sequenced seven non-normalized transcriptomes of $H$. diversicolorthat covered whole early developmental period from fertilized egg to postlarva (NCBIBioProject ID: 86631). Two important data sets were obtained from these studies: one is the assembly gene sequences, the other is a table containing relative expression levels of Top 600 most abundant genes in seven developmental stages. Base on these, in this study, we selected a batch of genes that expressed most stably in the gene expression context, cloned and resequenced these genes, and performed qPCR to confirm the expression stabilities. Best ICGs were identified and some features of early development of small abalone were further characterized, such as activity of the mitochondrial electron transport chain (mtETC) and overall mRNA abundances. Most interestingly, a Y-box binding protein 1 homolog gene (YB1) was confirmed to be very stable expressed during the investigated period. It is the first time to report that the multi-functional regulator gene could be used as an internal control on early developmental biology studies.
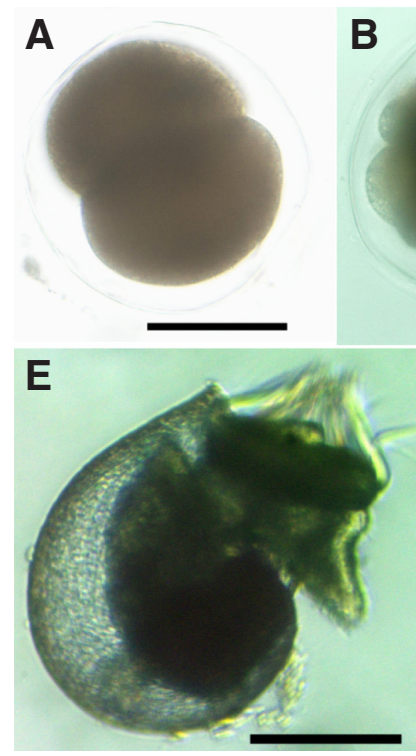

Fig. 1. Embryos and larvae of $\boldsymbol{H}$. diversicolor. (A) 2-cell stage (2CELL, 0.5 hpf). (B) Morula stage (MORU, 3.3 hpf). (C) Trochophore stage (TROC, 9.1 hpf). (D) Veliger at 19 hpf (19VEL). (E) Veliger at 58 hpf (58VEL). (F) Late competent veliger at 74 hpf (74VEL). (G) Postlarva after 3 days settlement (144PL, 144 hpf). Scale bar, $100 \mu \mathrm{m}$.

\section{Results}

\section{Full-length cDNA samples with high quality were obtained}

Seven synchronized embryo/larvae samples that covered whole early developmental period from fertilized egg to postlarva were collected (Fig. 1). In this sampling, hatching of trochophore happened at around 9.1 hours post-fertilization (hpf) and settlement peak of completive veliger happened at 65-74 hpf. At 74 hpf, swimming active of a large amount of veliger became weak and rested on the tank bottom. For the reason of high density of the larvae and flourishing of protozoa on the bottom, those larvae would be invaded by protozoa and degraded in 3-5 hours. At this time point, we sampled the larvae resting on bottom and named as 74VEL. Integrates of total RNA of the seven samples were evaluated by agarose gel electrophoresis and the electrophoretic behaviors showed typical molluscan pattern (Barcia et al., 1997) (Fig. S1). For RNA preservation and to promise data quality and comparability, we transformed total RNA into full-length cDNA for each sample with identical experimental procedure. A sample named MixA was prepared by mixing equal amount of each of the 7 developmental cDNAs.

\section{Ten candidate control genes were cloned and resequenced}

From a batch of candidate genes, ten genes were successfully cloned and resequenced. Their sequences were submitted to GenBank and were used to evaluate stability. They participate in different biological processes, such as mtETC (COXI, COXII and ND5), DNA/RNA binding and RNA transcription ( $Y B 1$ and $P A B P 1$ ), translation (YB1, PABP1, EIF5A, RPS18 and RPL3), cell skeleton (TUBB), and polyamine metabolism (OAZ1) (Table 1). Table 1 also showed the relative expression levels of these genes in transcriptomics analysis. Expression variations were conveniently indicated by coefficients of variation (CV) with most stable genes at the top and lest stable genes at the bottom. Among the Top 600 most abundant genes, EIF5A, YB1, RPL3 and OAZ1 were within Top 10 most stable gene list (in submitting). Because Has-NACA, Has-DAu1506 and Has-ubiquitin had been chosen as ICGs for study transcriptional changes during pelagic-benthic transition of $H$. asinina (Williams et al., 2009), their orthologs of $H$. diversicolor were also listed in the table to compare stabilities. It could be concluded that in a period spanning from fertilized egg to postlarva, though the four genes within Top 10 most stable gene list have 1.73-2.13 folds of variations, they still are obviously more stable than the three ICGs used in pelagic-benthic transition studies.

\section{Best internal control genes}

Primers of the ten genes for qPCR were designed as listed in Table 2. Except RPL3, most of them amplified sharp bands with designed sizes (Fig. S2). PCR efficiency of each primer pair was also evaluated (Table 2). It showed except RPL3, other 9 primer pairs had 
TABLE 1

RELATIVE EXPRESSION OF 10 CANDIDATE CONTROL GENES

\begin{tabular}{|c|c|c|c|c|c|c|c|c|c|c|}
\hline Accessions & Symbol & Name & 2CELL & MORU & TROC & 19VEL & 58VEL & 74VEL & 144PL & CV \\
\hline JN997410 & EIF5A & Eukaryotic translation initiation factor $5 \mathrm{~A}$ & 223 & 217 & 288 & 273 & 166 & 178 & 274 & 0.21 \\
\hline JN997407 & YB1 & Y-box protein 1 & 1309 & 1654 & 1438 & 1853 & 1494 & 2195 & 1123 & 0.23 \\
\hline JN997411 & $R P L 3$ & $60 \mathrm{~S}$ ribosomal protein $\mathrm{L} 3$ & 514 & 488 & 663 & 425 & 872 & 652 & 602 & 0.25 \\
\hline FJ809756 & $O A Z 1$ & Ornithine decarboxylase antizyme 1 & 4703 & 2359 & 3252 & 3980 & 2200 & 3441 & 2368 & 0.30 \\
\hline JN997417 & ND5 & NADH-ubiquinone oxidoreductase chain 5 & 8549 & 12736 & 9133 & 11361 & 13861 & 5870 & 4461 & 0.37 \\
\hline JN997408 & COXI & Cytochrome c oxidase subunit 1 & 31985 & 41541 & 20012 & 33932 & 31001 & 15297 & 9744 & 0.43 \\
\hline JN997409 & COXII & Cytochrome c oxidase subunit 2 & 31419 & 54169 & 28084 & 36423 & 42372 & 18321 & 10716 & 0.46 \\
\hline JN997412 & RPS18 & $40 S$ ribosomal protein $\mathrm{S} 18$ & 69 & 515 & 354 & 365 & 332 & 1127 & 411 & 0.72 \\
\hline JN997413 & TUBB & Beta-tubulin & 0 & 407 & 398 & 486 & 374 & 1008 & 41 & 0.86 \\
\hline JN997416 & $P A B P 1$ & Polyadenylate-binding protein 1 & 16309 & 3848 & 2388 & 1701 & 2490 & 1660 & 383 & 1.33 \\
\hline JU062807 & $N A C A^{*}$ & nascent polypeptide-associated complex alpha & 51 & 515 & 332 & 456 & 415 & 237 & 342 & 0.46 \\
\hline JU071609 & ubiquitin* & ubiquitin & 17 & 542 & 155 & 152 & 498 & 415 & 465 & 0.65 \\
\hline JU068308 & DAu1506* & DAu1506 & 34 & 27 & 44 & 122 & 83 & 0 & 0 & 1.00 \\
\hline
\end{tabular}

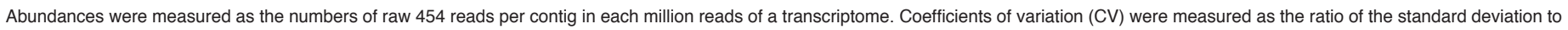

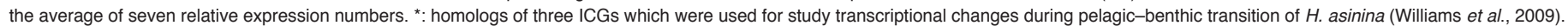

TABLE 2

PRIMERS OF 10 CANDIDATE CONTROL GENES USED IN qPCR

\begin{tabular}{|c|c|c|c|c|}
\hline Symbol & Forward primer & Reverse primer & Size (bp) & PCR efficiency \\
\hline RPS18 & CCCGTCAATACAAGATTCCAG & CACCAACAGTTCTTCCACGAC & 222 & 2.02 \\
\hline EIF5A & GGACGCAGCGGACGAGACTTT & GGCCATGTTTCCCGGTCTTTG & 158 & 1.97 \\
\hline COXI & ACTTCATAGTAATCGTATGGGAATC & TGGTAACAATTAGGTGTTTCG & 140 & 1.98 \\
\hline YB1 & AAGTTCTAGCAACGAGGGTCA & GGTATTTCTTTTGGGTTGTTCTTC & 141 & 2.02 \\
\hline TUBB & CTCACATCCAGAGGAAGCCAACA & ATGGACATGCGACCTCGGAAC & 152 & 1.99 \\
\hline$P A B P 1$ & CCAGCAGTCAGTGGTCATCC & AATACAGCAACAGCCTCATCAAC & 243 & 1.97 \\
\hline ND5 & ATAGCAGCGCCAACTCCTGTC & CCAAACTAGCCATCATCACCC & 242 & 1.96 \\
\hline$O A Z 1$ & GAACTCCTTGGCACATCAGAC & TCAGGAAGAATGCCAGAAGGT & 141 & 2.01 \\
\hline COXII & ТСССТTАСАТСТСGСТАСАТС & TAATTGTTAGCAGGCAGGATA & 151 & 1.98 \\
\hline RPL3 & GCATCCCAGCAGAGTTCAGTA & CACAАСАTСССТTCAGCATCA & 242 & 1.74 \\
\hline
\end{tabular}

efficiencies of 1.96-2.02 and suit for qPCR. The RPL3 gene thus was excluded from qPCR analysis because both PCR band and efficiency of RPL3 primer pair were not reached quality thresholds.

The raw $\mathrm{Ct}$ values of the nine genes in 8 samples were showed in Fig. 2. It could be seen that COXII, COXI, ND5 and TUBB expressed much abundance $(\mathrm{Ct} \approx 9.5)$, and then followed by $O A Z 1$ (11.5), PABP1 (12.3), YB1 (13.8), RPS18(14.2) and EIF5A(14.3). No gene had $C t$ value higher than 15 , it could be reasoned that these candidate genes were all selected from the Top 600 most abundant genes in early developmental stages and their expres-

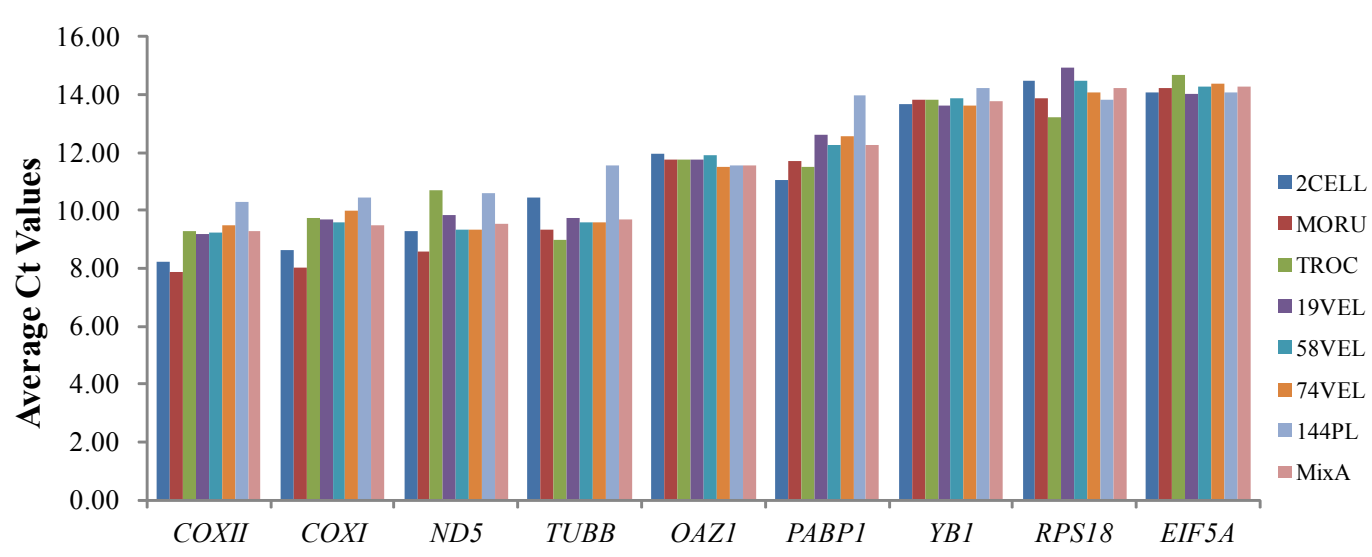

Fig. 2. Raw Ct values of nine control genes during developmental stages. sion levels are basically high. It also could be observed that $O A Z 1$, YB1 and EIF5A had lowest fluctuation.

By input relative concentration data into geNorm (Vandesompele et al., 2002), the nine candidate genes were ranked by average expression stability $(\mathrm{M})$ values with least stable gene at the left and the two most stable genes at the right (Fig. 3A). These genes exhibited stability range of $0.28-0.73$, with three most stable genes, $Y B 1 / O A Z 1$ and EIF5A, having Mvalues lower than 0.30. The stable rank of these genes evaluated by $\mathrm{qPCR}$ was well coincident with transcriptome analysis (Table 1$)$. The effect of adding an $(n+1)$ th ICG to normalization was evaluated by geNorm pairwise variation $(\mathrm{V})$ values, which indicate the variation between two sequential normalization factors containing an increasing number of genes (Fig. 3B). It was apparent that the inclusion of a third gene (EIF5A) had no significant effect $(V 2 / 3=0.087$, much lower than the threshold of 0.15 ) for overall normalization. However, it showed that adding a fourth gene (COXII) had a significant effect (V3/4 $=0.188$, larger than 0.15 ) to 
A

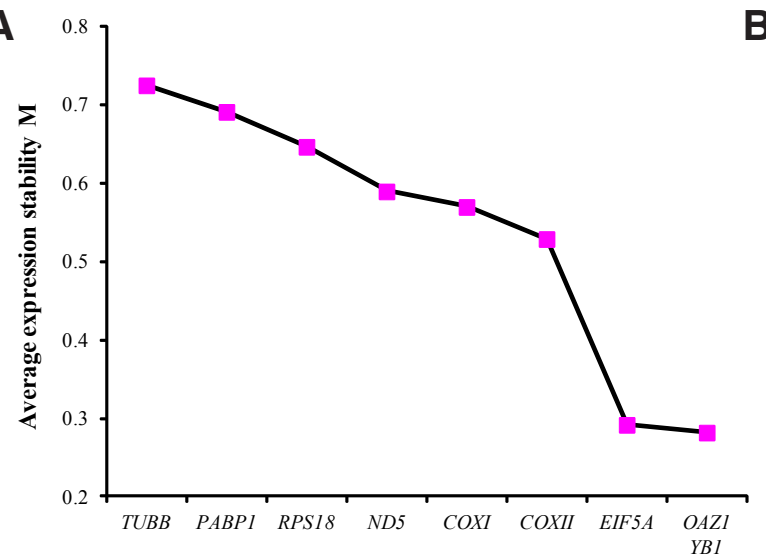

B

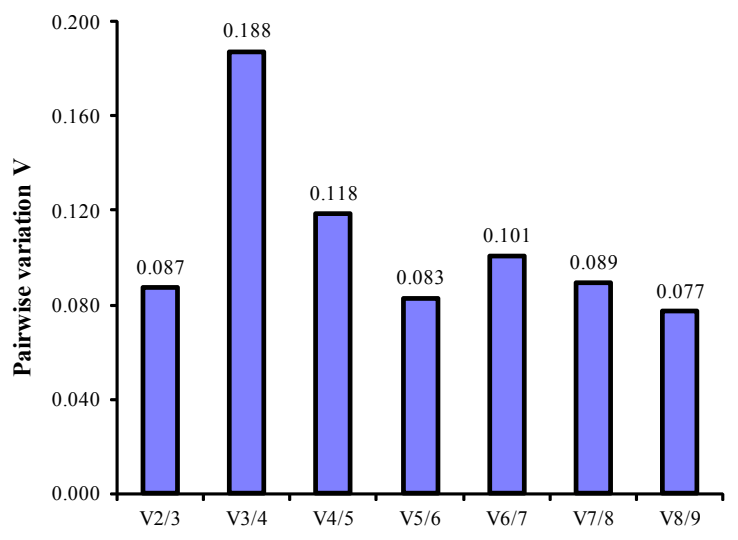

Fig. 3. Evaluation of internal control genes (ICGs) by geNorm. (A) Average expression stability values of nine control genes. (B) Pairwise variation values of adding an $(n+1)$ th control genes to normalization.

normalization factor. Normally, the normalization factor would become better after including an $n+1$ gene if $\mathrm{Vn} / \mathrm{n}+1$ larger than 0.15 (Vandesompele et al., 2002). But in this case, COXIIgene showed high co-regulate expression pattern with some other candidate genes as demonstrated below, thus it would not be included for normalization proposes. By above analysis, we concluded that the three genes, YB1, OAZ1 and EIF5A, were stable enough to normalize expression data for early development study of small abalone. For convenient purposes, jointly using two genes, such as $Y B 1$ and $O A Z 1$, also would be reliable.

\section{Relative expression of six genes in early development}

Using YB1/OAZ1 as ICGs, relative expressions of six genes, COXI, COXII, ND5, PABP1, RPS18 and TUBB, were determined (Fig. 4). Because EIF5A showed similar stability with the two ICGs, its expressions were excluded from calculation. In an overall view, these six genes expressed in a range of 4-7 folds variation during early development of small abalone, which means related biological processes change dramatically in this period. There were few literatures had patterned temporal dynamics of these fundamental processes in invertebrate larvae development. Thus we referred 454 expression data (Table 1) to compare with qPCR expression data by Spearman Rank Correlation test and those genes with strong positive correlations can reasonably portray related biological processes. In each comparison, 454 expressions of each gene were also normalized by corresponding 454 data of $Y B 1 / O A Z 1$ and rescaled to match the scales of the qPCR expressions. All six genes showed positive correlation $(r>0)$ by Spearman Rank Correlation test, and four of them (COXI, COXII, ND5 and PABP1) showed statistical significances $(P<0.1)$ (Fig. 4). It means by normalization of $Y B 1 / O A Z 1$, the two sets of expression are mainly consentaneous and the consistent temporal dynamics of fourgenes

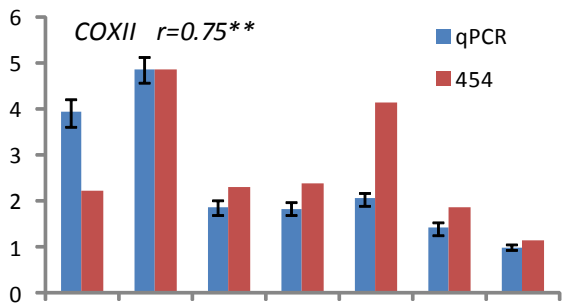

2CELL MORU TROC 19VEL 58VEL 74VEL 144PL

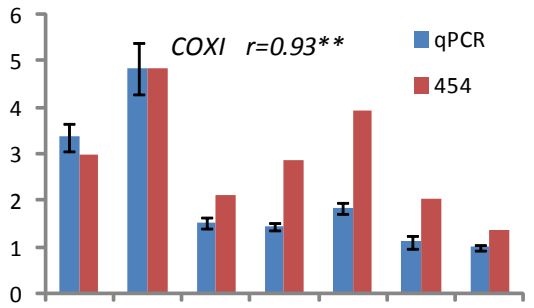

2CELL MORU TROC 19VEL 58VEL 74VEL 144PL

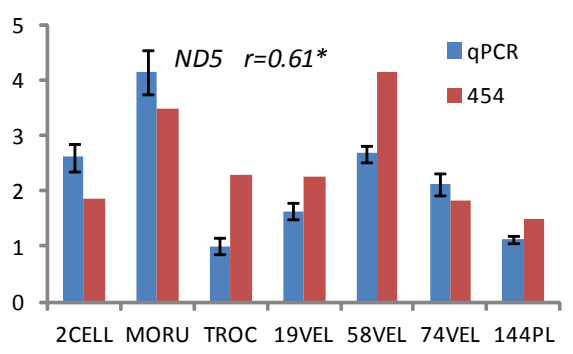

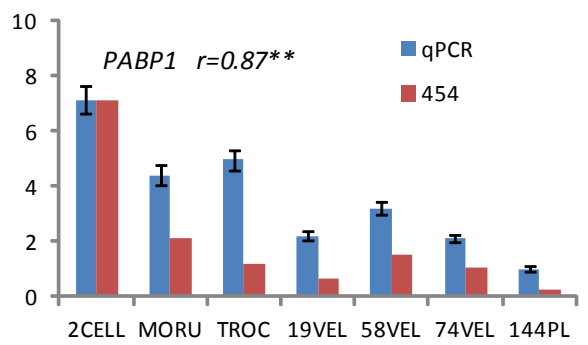
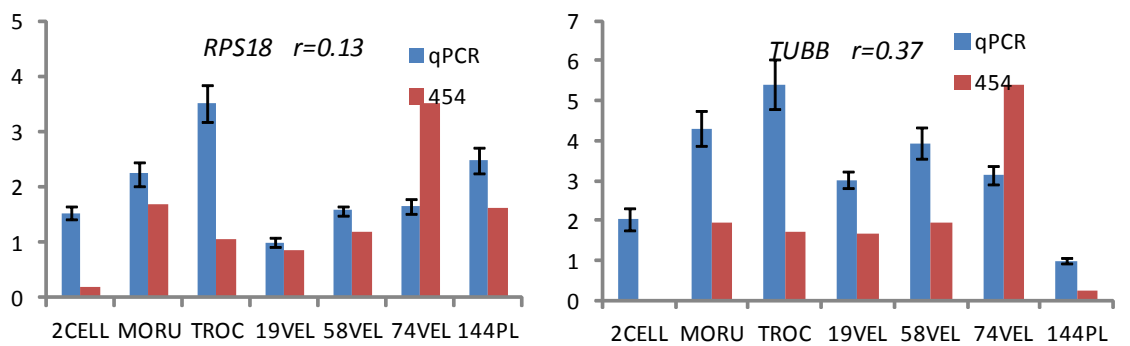

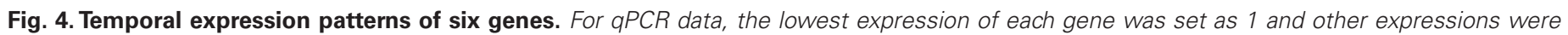

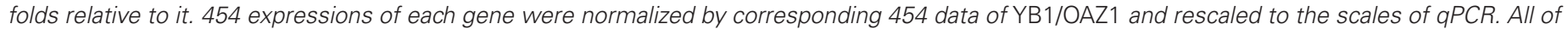

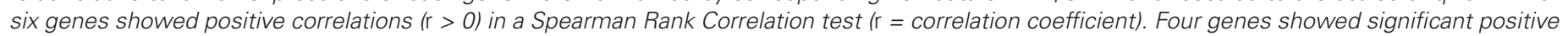
correlations. Significance codes: ${ }^{*}=p<0.1 ;{ }^{*}=p<0.05$. 
(COXI, COXII, ND5 and PABP1) are reliable.

COXI, COXII and ND5 showed identical temporal expression patterns. They all showed high expression at morula stage and at the eve of settlement (veliger at 58hpf) by both 454 and qPCR expression data. Interestingly, their protein products are components of mtETC. The consensus of temporal expression patterns suggest that the $\mathrm{mtETC}$ are likely co-regulated during abalone early developmental period, and thus reflect that metabolic activity in embryo/larvae are much more active at morula and eve of settlement. PABP1 highest expressed at fertilized egg (2 cells) and had a descending trend at following development, excepting that it was a little up-regulated at the eve of settlement ( $58 \mathrm{hpf})$. PABP1 protein has main functions to bind poly $(A)$ tails of $m R N A$ and then stabilize them or initial translation (Craig et al., 1998), thus expression level of PABP1 may reflect overall mRNA abundance. It suggests that overall mRNA abundance of abalone larvae is highest at fertilized eggs and then fast descends at following developmental stages. The pattern was partially matched with that of ascidians larvae: during the period between hatching and obtaining competence, mRNA abundances of ascidians larvae appears to be low (Green et al., 2002) and expression of a large number of transcripts dropped apparently (Jackson et al., 2002). However, a little up-regulating of PABP1 at the eve of settlement means overall mRNA abundance may increase when abalone larvae become competence.

\section{Discussion}

Candidate ICGs should be stable across various biological conditions. In most cases, candidate ICGs were selected from housekeeping genes, which were a priori hypothesized that the fundamental bioprocesses were stable. However, during early developmental period of marine invertebrates, most of bioprocesses are unsteady. On the other hand, gene sequences and expression data of marine invertebrates were very limited and thus it was difficult to get enough candidate ICGs to evaluate their stabilities. After early developmental transcriptomes of abalone were sequenced and analyzed in our lab, genes were ranked by their expression stabilities. It was the first opportunity to select a bunch of candidate ICGs in global vision for abalone animals. From 600 actively expressed genes, four genes (YB1/OAZ1/EIF5A/RPL3) were top $1.67 \%(10 / 600)$ most stable and were selected as candidate ICGs. Totestify whether the ranking of stability by transcriptomics analysis was believable, other 6 genes with various stabilities were also selected. qPCR-geNorm evaluation in this study showed that these candidate genes were ranked as the ranking of transcriptomic analysis. So that the stability ranked by transcriptomic analysis is mainly believable. At the foundation that the stability ranking is believable and the three genes (YB1/OAZ1/EIF5A), which passed strict quality control, are top $1.67 \%$ stable within those actively expressed genes, it is reliable to apply the three genes as ICG in most occasions. Jointly using two or more genes, which involved in different bioprocesses, make it more reliable because fluctuations of one gene could be smoothed by other genes.

It is first time to report that YB1 gene could be used as ICG for early developmental study. The putative protein (280 aa) of YB1 shows typical Y-box protein structure that it includes a highly conserved $\mathrm{N}$-terminal cold-shock domain (CSD) plus four basic C-terminal domains containing arginine clusters and acidic amino acid clusters, where each cluster contains 15-25 residues. After aligned it with 12 homologous sequences from other animal species in a region containing the CSD domain and following one clusters (total about 112aa), phylogenic tree of YB1 was constructed (Fig. 5). The CSD region (91aa) of $H$. diversicolor YB1 (HdYB1) shows $76 \%-89 \%$ identities to other homologs. It is obvious that mollusk YB1s were high-reliably classed together. These analyses indicate HdYB1 has high identical structure to its homologs, so that HdYB1 protein would play similar molecular functions as other YB1 proteins that were well studied. Y-box proteins involved in a wide range of important cellular functions, such as transcriptional regulation, translational regulation, alternative splicing of mRNA, DNA repair and cell proliferation (Kohno et al., 2003). YB1 not only can recognize and bind the Y-box in DNA, it also can bind various mRNA to delay their translation or maintain their stability (Bouvet and Wolffe, 1994). It was speculated to act as translational repressor to compete with the elF4E-driven translation initiation complex for binding to the mRNA 5' cap (Evdokimova et al., 2006, Evdokimova et al., 2001). Because of its important roles in mRNA stabilization, cell proliferation and cell death, YB1 was applied in cancer studies as an important biomarker (Braithwaite et al., 2006, Kuwano et al., 2004). APY1 of Aplysia californica, the closest homolog of HdYB1, showed strong RNA-binding activity in vitro (Skehel and Bartsch, 1994). During oogenesis and early development, YB1 proteins were proved to have strong activities to mask maternal mRNA from translation (Bouvet and Wolffe, 1994, Ranjan et al., 1993). These literatures suggest that HdYB1 has important functions in translational regulation and masking maternal mRNA. It was reported ascidian Y-box protein gene CiYB expresses three different transcripts by alternate splicing in embryo/larvae stages (Wada et al., 1998). Thus there exists possibility that different transcripts of $H d Y B 1$ may play balance games during the period. But from transcriptome assembly data, we found no evidences

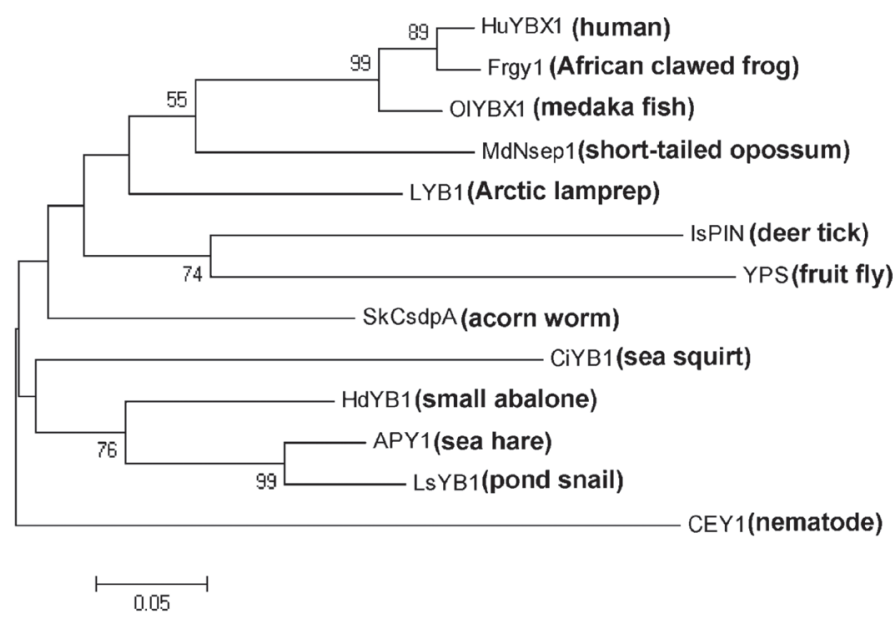

Fig. 5. Phylogeny of YB1. Neighbor-joining tree was constructed from an alignment of CSD domains plus following one clusters (total about 112aa) by MEGA version 5.0 (Tamura et al., 2011). The percentages of 1000 bootstrap replicates supporting adjacent node over $50 \%$ were labeled. Branch lengths reflect distance as calculated by a PAM-Dayhoff protein distance matrix. The GenBank accession numbers are as follows: HuYBX1, NM_004559; Frgy1, XELFRGY1; OIYBX1, NM_001104673; LYB1, EU874393; MdNsep1, XM_001376401; SkCsdpA, XM_002732389; IsPIN, XM_002434845; YPS, NM_079309; CiYB1, NM_001078571; HdYB1, JN997407; APY1, NM_001204631; LsYB1, AY577334; CEY1, NM_063965. 
that $H d Y B 1$ has alternate splicing (unpublished data). If it had, alternate transcripts must have expressed in orders of magnitude lower than the present transcript and would have minor impacts to validity of YB1 as an ICG. In the background that many fundamental processes vary several folds during early development, steadily expression of the multi-function regulator in the entire period indicates that some stable elements are involved in regulation of cell cycle and cell proliferation during abalone early developments. Its mechanisms and consequences need to be further clarified.

In conclusion, this is first systematical evaluation for ICGs that can be applied in early-developmental biology studies of abalone animals. Three genes ( YB1, OAZ1 and EIF5A) were proved to be stable expressing during the whole period from fertilized egg to postlarva by both qPCR and transcriptome data. We first reported that metabolic activities of embryo/larvae may much more active at morula and eve of settlement. Overall mRNA abundance may be highest at fertilized egg and descending at following stages excepting at the eve of settlement (58 hpf) when transcriptional activity may have a little increasing. It also is the first time to report the multi-functional gene YB1 could be used as an internal control on early developmental biology studies. Because of functional importance of YB1, mechanisms and consequences of its stable expression in whole early period are worthy to be further studied.

\section{Materials and Methods}

\section{Sample collection}

Larvae preparation of small abalone $\mathrm{H}$. diversicolor was carried out in Hongyun abalone farm (Zhangzhou, Fujian, China) in September, 2010. The fertilization and spawning of small abalone were followed the You's work (You et al., 2010). After fertilization and spawning, gametes were gently sieved through a $130-\mu \mathrm{m}$ pore-size nylon mesh. The embryo or larval were cultured in $23-25^{\circ} \mathrm{C}$ fresh filtered sea water (FSW) which was exchanged regularly. The morphological changes were checked with a light microscope. Seven different developmental stages were collected: fertilized eggs in two-cell stage (2CELL, $0.5 \mathrm{hpf}$ ), morula stage (MORU, $3.3 \mathrm{hpf}$ ), trochophore stage (TROC, $9.1 \mathrm{hpf}$ ), $19 \mathrm{hpf}$ veliger (19VEL), $58 \mathrm{hpf}$ veliger (58VEL), late competent veliger larva (74VEL, $74 \mathrm{hpf}$ ), postlarva after 3 days settlement (144PL, $144 \mathrm{hpf}$ ). Developmental synchrony was strictly monitored with a microscope to ensure that over $80 \%$ of larvae in each sample were in same developmental stages. Each collection was washed with $\mathrm{ddH}_{2} \mathrm{O}$ and preserved in Trizol (Invitrogen) immediately. Before RNA isolation, samples were stocked at a $-80^{\circ} \mathrm{C}$ freezer.

\section{RNA extraction and $c D N A$ procedure}

Total RNA of each sample was extracted by Trizol kit (Invitrogen). Integrate of RNA samples were checked by electrophoresis in 1.2\% agarose gels. Messenger RNAs were further purified with MicroPoly(A) Purist kit (Ambion) by following producer's manual. First strand cDNA (fs-cDNA) was synthesized from 50-200 ng of mRNAusing SMART TM PCR CDNASynthesis kit (Clontech) in a $10 \mu \mathrm{L}$ system with $2 \mu \mathrm{L} 5 \times$ First-strand synthesis buffer, 0.5 $\mu \mathrm{L} 10 \mathrm{mM}$ dNTPs, $1 \mu \mathrm{L} 0.1 \mathrm{mM}$ DTT, $1 \mu \mathrm{L} 10 \mu \mathrm{M}$ Template-switch primer,

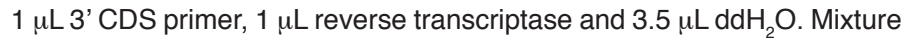
was incubated at $42^{\circ} \mathrm{C}$ for $90 \mathrm{~min}$ and then stop the reaction by incubated at $70^{\circ} \mathrm{C}$ for $10 \mathrm{~min}$. Double-stranded cDNA (ds-cDNA) were further synthesized with following conditions: each $25 \mu \mathrm{L}$ system, which contained 1 $\mu \mathrm{L} 20 \times$ diluted fs-cDNA, $2.5 \mu \mathrm{L} 10 \times$ Pyrobest Buffer II (TaKaRa), $2 \mu \mathrm{L} 2.5$ mM dNTPs, $1 \mu \mathrm{L} 10 \mu \mathrm{M}$ 5' cap-primer, $1 \mu \mathrm{L} 10 \mu \mathrm{M}$ 3' CDS primer, $0.25 \mu \mathrm{L}$ Pyrobest DNA polymerase (TaKaRa) and $17.25 \mu \mathrm{L} \mathrm{ddH_{2 }} \mathrm{O}$, was performed PCR as the program: $95^{\circ} \mathrm{C} 1 \mathrm{~min},\left(95^{\circ} \mathrm{C} 15 \mathrm{~s}, 65^{\circ} \mathrm{C} 30 \mathrm{~s}, 72^{\circ} \mathrm{C} 6 \mathrm{~min}\right) \times 12$ cycles, $72^{\circ} \mathrm{C} 5 \mathrm{~min}$. The ds-cDNA products were purified with Axygen PCR Purification kits (Axygen). DNA concentrations were determined by Qubit Fluorescent (Invitrogen) and a sample named MixA was prepared by mixing equal amount of each of the 7 developmental cDNAs.

\section{Sequencing confirmation of candidate genes}

Seven non-normalized transcriptomes corresponding to seven developmental stages in this study were previously sequenced (NCBI BioProject ID: 86631). The transcriptomic data provided gene background and a table containing relative expression levels of top 600 most abundance genes in seven developmental stages. Relative expression was defined as raw reads of each gene per million 454 pyrosequencing reads in a transcriptome. Several most stable genes and some other housekeeping genes commonly used as ICG were selected from the gene table. Forward and reverse primers were designed at both ends of each candidate genes and PCR were performed as the condition: $1 \mu \mathrm{L}$ MixA (1 $\left.\mathrm{ng} \mu \mathrm{L}^{-1}\right), 2.5 \mu \mathrm{L}$ 10xPyrobest Buffer II, $2 \mu \mathrm{L} 2.5 \mathrm{mM}$ dNTPs, $1 \mu \mathrm{L} 10 \mu \mathrm{M}$ Forward-primer, 1 $\mu \mathrm{L} 10 \mu \mathrm{M}$ Reverse-primer, $0.15 \mu \mathrm{L}$ Pyrobest DNA polymerase, add $\mathrm{dd}_{2} \mathrm{O}$ to $25 \mu \mathrm{L} ; 95^{\circ} \mathrm{C}, 1 \mathrm{~min},\left(95^{\circ} \mathrm{C} 30 \mathrm{~s}, 55^{\circ} \mathrm{C} 30 \mathrm{~s}, 72^{\circ} \mathrm{C} 3 \mathrm{~min}\right) \times 30$ cycles. The PCR products were purified with Axygen PCR Purification kits and cloned into pUC19/Sma I vector. Positive clones were sent to GenScript (Nanjing, China) to perform Sanger sequencing.

\section{Design and evaluation of primers for $q P C R$}

Primers for qPCR were design by Primer 5.0 software (Premier Biosoft International). Besides common requirements for primer design, some other thresholds were reached: Tm were around $60^{\circ} \mathrm{C}$, amplicon lengths were 100-250 bp, and primers were BLASTn to GenBank nr database and to our transcriptome database to avoid high-similarity homologous sequences. Primers were synthesized by Invitrogen (Guangzhou, China). Accuracies and specificities of primer pairs were evaluated by PCR using MixA as template and products were checked by $1.5 \%$ agarose gel electrophoresis. Those primer pairs which achieved single sharp band and correct amplicon length were candidates for qPCR.

\section{qPCR}

PCR efficiency of each primer pair was evaluated by dilute $\mathrm{GPCR}$. Five dilutions of MixA ( $1 \mathrm{ng} \mu \mathrm{L}^{-1}, 0.1 \mathrm{ng} \mu \mathrm{L}^{-1}, 0.01 \mathrm{ng} \mu \mathrm{L}^{-1}, 0.001 \mathrm{ng} \mu \mathrm{L}^{-1}$

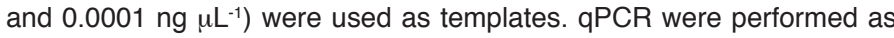
the condition: $1 \mu \mathrm{L}$ forward primer $(5 \mu \mathrm{M}), 1 \mu \mathrm{L}$ reverse primer $(5 \mu \mathrm{M}), 1$ $\mu \mathrm{L}$ template, $12.5 \mu \mathrm{L} 2 \times$ TransStart Green qPCR SuperMix (Transgene Biotech, Beijing, China), add ddH ${ }_{2} \mathrm{O}$ to $25 \mu \mathrm{L} ; 95^{\circ} \mathrm{C} 3 \mathrm{~min},\left(95^{\circ} \mathrm{C} 10 \mathrm{~s}, 55^{\circ} \mathrm{C}\right.$ $\left.15 \mathrm{~s}, 72^{\circ} \mathrm{C} 15 \mathrm{~s}\right) \times 45$ cycles. PCR and data collection were performed by a Rotor-Gene 3000 Real-time PCR instrument (Corbett). Each reaction was repeated three times. $C_{t}$ values and $P C R$ efficiencies were calculated by Rotor-Gene 6.0.14 software (Corbett). The seven developmental ds-

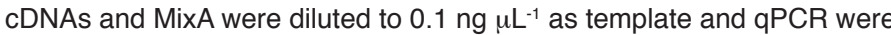
performed as described above. Each reaction was repeated three times.

\section{Statistical analysis}

The $\mathrm{Ct}$ values for each gene were transformed into comparative concentration using the $2^{-\Delta C t}$ method where $\Delta C_{t}=C_{t \text { stage }}-C_{t \text { MixA }}$ and the data were inputted into geNorm 3.5 software (Vandesompele et al., 2002), which then calculated average expression stability ( $M$ value) of each gene in different developmental stages and pairwise variation ( $\mathrm{V}$ value) of adding an $(n+1)$ th control genes to normalization. After such analysis, optimal number of most stable control genes for normalization was determined. Relative expressions of each gene, except the most stable genes, in different developmental stages were finally normalized by the determined control genes. To evaluate correspondence of the two data set of relative expression, qPCR and 454, the latter were also normalized by the same control genes with 454 expression data and then compared with qPCR data using Spearman Rank Correlation tests in Microsoft Excel.

\section{Acknowledgments}

This study was supported in part by the National Natural Science Foundation of China (General Program, No. 40976093), by the National Basic Research Program of China (973) (No. 2010CB126403), and by Hi-Tech 
Research and Development (863) Program of China (No. 2012AA10A412).

\section{References}

BARCIA, R., LOPEZ-GARCIA, J.M. and RAMOS-MARTINEZ, J.I. (1997). The $28 \mathrm{~S}$ fraction of rRNA in molluscs displays electrophoretic behaviour different from that of mammal cells. Biochem Mol Biol Int 42: 1089-1092.

BOUVET, P. and WOLFFE, A.P. (1994). A role for transcription and FRGY2 in masking maternal mRNA within Xenopus oocytes. Cell 77: 931-941.

BRAITHWAITE, A.W., DEL SAL, G. and LU, X. (2006). Some p53-binding proteins that can function as arbiters of life and death. Cell Death Differ 13: 984-993.

CRAIG, A.W., HAGHIGHAT, A., YU, A.T. and SONENBERG, N. (1998). Interaction of polyadenylate-binding protein with the elF4G homologue PAIP enhances translation. Nature 392: 520-523.

DEGNAN, B.M., DEGNAN, S.M., FENTENANY, G. and MORSE, D.E. (1997). A Mox homeobox gene in the gastropod mollusc Haliotis rufescens is differentially expressed during larval morphogenesis and metamorphosis. FEBS Lett411:119-122.

EVDOKIMOVA, V., OVCHINNIKOV, L.P. and SORENSEN, P.H. (2006). Y-box binding protein 1: providing a new angle on translational regulation. Cell Cycle 5: 1143-1147.

EVDOKIMOVA, V., RUZANOV, P., IMATAKA, H., RAUGHT, B., SVITKIN, Y., OVCHINNIKOV, L.P. and SONENBERG, N. (2001). The major mRNA-associated protein YB-1 is a potent 5' cap-dependent mRNA stabilizer. EMBO J 20: 5491-5502.

GIUSTI, A.F., HINMAN, V.F., DEGNAN, S.M., DEGNAN, B.M. and MORSE, D.E. (2000). Expression of a ScrlHox5 gene in the larval central nervous system of the gastropod Haliotis, a non-segmented spiralian lophotrochozoan. Evol Dev 2: 294-302.

GORDON, H.R. and COOK, P. (2001). World abalone supply, markets and pricing: historical, current and future. J Shellfish Res 20: 567-570.

GREEN, K.G., RUSSELL, B.R., CLARK, R.C., JONES, M.J., GARSON, M.G., SKILLETER, G.S. and DEGNAN, B.D. (2002). Asponge allelochemical induces ascidian settlement but inhibits metamorphosis. Mar Biol 140: 355-363.

JACKSON, D., LEYS, S.P., HINMAN, V.F., WOODS, R., LAVIN, M.F. and DEGNAN, B.M. (2002). Ecological regulation of development: induction of marine invertebrate metamorphosis. Int J Dev Biol 46: 679-686.

JACKSON, D.J., ELLEMOR, N. and DEGNAN, B.M. (2005). Correlating gene expression with larval competence and the effect of age and parentage on metamorphosis in the tropical abalone Haliotis asinina. Mar Biol 147: 681-697.
KOHNO, K., IZUMI, H., UCHIUMI, T., ASHIZUKA, M. and KUWANO, M. (2003). The pleiotropic functions of the Y-box-binding protein, YB-1. Bioessays 25: 691-698.

KUWANO, M., ODA, Y., IZUMI, H., YANG, S.J., UCHIUMI, T., IWAMOTO, Y., TOI, M., FUJII, T., YAMANA, H., KINOSHITA, H. et al., (2004). The role of nuclear Y-box binding protein 1 as a global marker in drug resistance. Mol Cancer Ther 3: $1485-1492$

RADONIC, A., THULKE, S., MACKAY, I.M., LANDT, O., SIEGERT, W. and NITSCHE, A. (2004). Guideline to reference gene selection for quantitative real-time PCR. Biochem Biophys Res Commun 313: 856-862.

RANJAN, M., TAFURI, S.R. and WOLFFE, A.P. (1993). Masking mRNA from translation in somatic cells. Gene Dev 7: 1725-1736.

SAWATPEERA, S., UPATHAM, E.S., KRUATRACHUE, M., CHITRAMVONG, Y.P., SONGCHAENG, P., PUMTHONG, T. and NUGRANAD, J. (2001). Larval development in Haliotis asinina Linnaeus. J Shellfish Res 20: 593-601.

SKEHEL, P.A. and BARTSCH, D. (1994). Characterization of a Y-Box factor from Aplysia californica. Gene 145: 231-235.

TAMURA, K., PETERSON, D., PETERSON, N., STECHER, G., NEI, M. and KUMAR, S. (2011). MEGA5: molecular evolutionary genetics analysis using maximum likelihood, evolutionary distance, and maximum parsimony methods. Mol Biol Evol 28: 2731-2739.

VANDESOMPELE, J., DE PRETER, K., PATTYN, F., POPPE, B., VAN ROY, N., DE PAEPE, A. and SPELEMAN, F. (2002). Accurate normalization of real-time quantitative RT-PCR data by geometric averaging of multiple internal control genes. Genome Biol 3: RESEARCH0034.

WADA, M.R., OHTANI, Y., SHIBATA, Y., TANAKA, K.J., TANIMOTO, N. and NISHIKATA, T. (1998). An alternatively spliced gene encoding a $Y$-box protein showing maternal expression and tissue-specific zygotic expression in the ascidian embryo. Dev Growth Differ 40: 631-640.

WAN, Q., WHANG, I., CHOI, C.Y., LEE, J.S. and LEE, J. (2011). Validation of housekeeping genes as internal controls for studying biomarkers of endocrine-disrupting chemicals in disk abalone by real-time PCR. Comp Biochem Physiol C Toxicol Pharmacol 153: 259-268.

WILLIAMS, E.A., DEGNAN, B.M., GUNTER, H., JACKSON, D.J., WOODCROFT, B.J. and DEGNAN, S.M. (2009). Widespread transcriptional changes pre-empt the critical pelagic-benthic transition in the vetigastropod Haliotis asinina. Mol Ecol 18: 1006-1025.

YOU, W.-W., KE, C.-H., LUO, X. and WANG, D.-X. (2010). Divergent selection for shell length in two stocks of small abalone Haliotis diversicolor. Aquac Res 41: 921-929. 


\section{Further Related Reading, published previously in the Int. J. Dev. Biol.}

Expression of prohormone convertase 2 and the generation of neuropeptides in the developing nervous system of the gastropod Haliotis

Scott F. Cummins, Patrick S. York, Peter H. Hanna, Bernard M. Degnan and Roger P. Croll Int. J. Dev. Biol. (2009) 53: 1081-1088

Expression patterns of Src-family tyrosine kinases during Xenopus laevis development Zoltan Ferjentsik, Radek Sindelka, Jiri Jonak

Int. J. Dev. Biol. (2009) 53: 163-168

Who came first--larvae or adults? origins of bilaterian metazoan larvae Belinda J Sly, Margaret S Snoke and Rudolf A Raff

Int. J. Dev. Biol. (2003) 47: 623-632

Evolution and developmental expression of nuclear receptor genes in the ascidian Herdmania

Christine Devine, Veronica F Hinman and Bernard M Degnan

Int. J. Dev. Biol. (2002) 46: 687-692

Ecological regulation of development: induction of marine invertebrate metamorphosis Daniel Jackson, Sally P Leys, Veronica F Hinman, Rick Woods, Martin F Lavin and Bernard M Degnan

Int. J. Dev. Biol. (2002) 46: 679-686

$$
5 \text { yr ISI Impact Factor }(2010)=2.961
$$

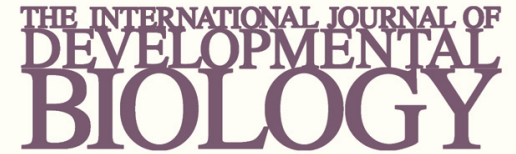

Volume 54 Nos. 6/7

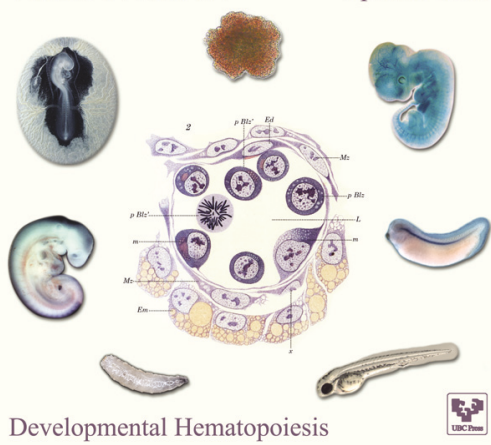

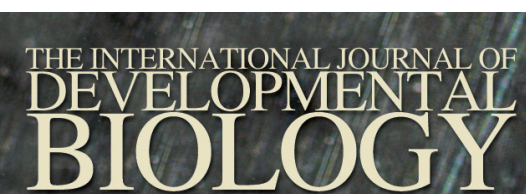
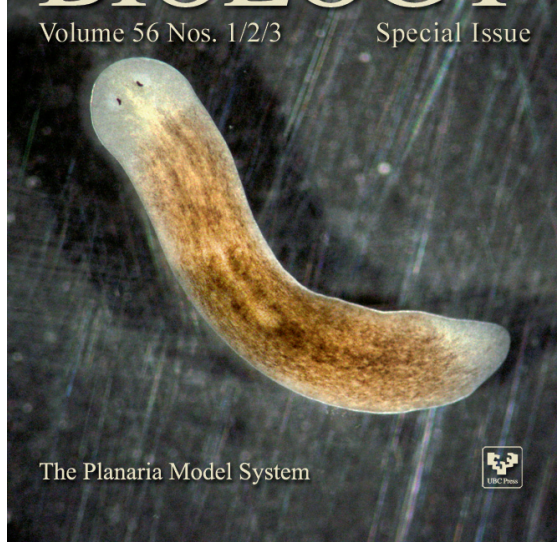
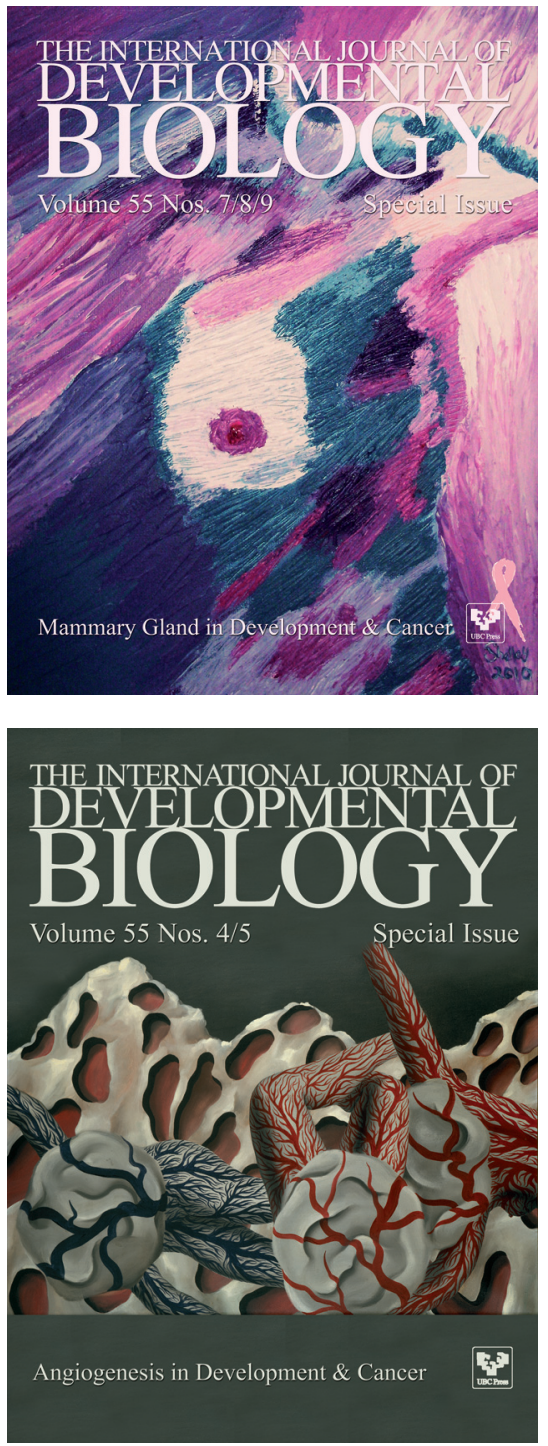